\title{
Release of Endogenous Excitatory Amino Acids from ON-type Bipolar Cells Isolated from the Goldfish Retina
}

\author{
Masao Tachibana and Takashi Okada \\ Department of Psychology, Faculty of Letters, The University of Tokyo, 7-3-1 Hongo, Bunkyo-ku, Tokyo 113, Japan
}

\begin{abstract}
Excitatory amino acids are presumed to be the transmitter of retinal bipolar cells. However, one of the essential criteria for the identification of the transmitter, its release from the cells upon depolarization, has not been demonstrated. This article examines the release of endogenous excitatory amino acids from bipolar cells and correlates this release with the influx of $\mathrm{Ca}^{2+}$. Bipolar cells with a large, bulblike axon terminal (ON-type cells with mixed inputs from rods and cones) were enzymatically isolated from the goldfish retina. Horizontal cells dissociated from the catfish retina were used as a probe of excitatory amino acids, because these cells can detect submicromolar concentrations of $L$-glutamate with high selectivity. An isolated bipolar cell was closely apposed to a dissociated horizontal cell, and each cell was voltage clamped by a patch pipette in the whole-cell clamp configuration. When the bipolar cell was depolarized from $-60 \mathrm{mV}$ to a potential more positive than $-40 \mathrm{mV}$ using a $500-\mathrm{msec}$ voltage pulse, an outward current ( $>20 \mathrm{pA}$ ) was recorded from the apposed horizontal cell, which was maintained at $+40 \mathrm{mV}$. The reversal potential of the current induced by the substance released from bipolar cells $\left(I_{\mathrm{rs}}\right)$ was close to $0 \mathrm{mV}$ and was almost identical to the responses evoked with ionophoretically applied L-glutamate. Both reversal potentials were shifted to the same, more negative value when the external $\mathrm{Na}^{+}$was replaced with choline. Furthermore, the $I_{\mathrm{rs}}$ was suppressed reversibly by the application of kynurenic acid, a glutamate antagonist. When the $\mathrm{Ca}$ current $\left(I_{C_{a}}\right)$ of the bipolar cell was blocked by $\mathrm{Cd}^{2+}$, the $I_{\mathrm{rs}}$ also disappeared. The peak amplitude of $I_{\mathrm{rz}}$ was closely related to that of the $I_{\text {ca. }}$. We conclude that mixed rod/cone ON-type bipolar cells of the goldfish retina release an endogenous excitatory amino acid or a closely related compound in a $\mathrm{Ca}^{2+}$-dependent manner.
\end{abstract}

Several lines of evidence suggest that the transmitter of retinal bipolar cells may be an excitatory amino acid. First, the signal transmission from bipolar cells to postsynaptic cells, that is, amacrine and ganglion cells, has been suggested to be sign conserving (Toyoda et al., 1973; Famiglietti et al., 1977; Naka, 1977; Toyoda and Fujimoto, 1984). Second, the postsynaptic

\footnotetext{
Received Oct. 3, 1990; revised Feb. 18, 1991; accepted Feb. 25, 1991.

We thank Dr. George Ayoub for comments on the manuscript and Tomomi Arimura and Kiyohiro Ono for their participation in the early part of the experiments and their excellent technical assistance. This work was supported by The Ministry of Education, Science and Culture (Japan) Grant-in-Aid for Scientific Research 63480111,01640505, 01659503, 02223105, and 02241203 to M.T.

Correspondence should be addressed to $M$. Tachibana at the above address.

Copyright (C) 1991 Society for Neuroscience 0270-6474/91/112199-10\$03.00/0
}

cells are sensitive to excitatory amino acids (Kato et al., 1985; Barnes and Werblin, 1987; Aizenman et al., 1988). Third, the synaptic transmission is modified by application of glutamate antagonists (Slaughter and Miller, 1983; Bloomfield and Dowling, 1985; Lukasiewicz and McReynolds, 1985). Furthermore, glutamate immunoreactivity is particularly prominent in bipolar cells (Ehinger et al., 1988; Ehinger, 1989; Marc et al., 1990). However, the release of endogenous excitatory amino acids has not been demonstrated because of the lack of appropriate glutamate probes with high sensitivity and selectivity.

Recently, a bioassay technique has been introduced for the detection of transmitter release. Excised membrane patches containing a high density of transmitter-gated channels have been used to detect the release of $\mathrm{ACh}$ from growth cones (Hume et al., 1983; Young and Poo, 1983) and neuromuscular junctions (Meriney et al., 1989) and the release of excitatory amino acids from photoreceptors (Copenhagen and Jahr, 1989). Also, an isolated neuron under whole-cell voltage clamp has been used to sense the release of GABA from retinal horizontal cells (Schwartz, 1987).

Horizontal cells, the second-order neurons of the retina, are highly sensitive to L-glutamate (Lasater and Dowling, 1982; Tachibana, 1985; Hals et al., 1986; O'Dell and Christensen, 1986, 1989), which is a putative transmitter of photoreceptors (Murakami et al., 1972; Marc and Lam, 1981; Ehinger et al., 1988; Kaneko and Tachibana, 1988; Ayoub et al., 1989; Copenhagen and Jahr, 1989). Thus, we used isolated horizontal cells under whole-cell voltage clamp as a glutamate probe and examined whether single, isolated bipolar cells could release endogenous excitatory amino acids. It was found that endogenous excitatory amino acids were released from bipolar cells when their $\mathrm{Ca}$ current was activated by membrane depolarization.

\section{Materials and Methods}

Preparation of horizontal cells. Horizontal cells were obtained from the catfish retina. The details of dissociation and culture procedures have been described previously (Tachibana, 1981). Eyes were enucleated from decapitated and pithed catfish (total body length, 12-17 cm). The retinas, which were detached from the pigment epithelium, were incubated twice in a low- $\mathrm{Ca}^{2+}$ solution containing cysteine-activated papain (5 mM L-cysteine dihydrochloride; Tokyo Chemical Industry Co. Ltd. Tokyo, Japan, C0517; $4 \mathrm{mg}$ papain/ml; Wako Pure Chemical Industries, Ltd., Osaka, Japan, 164-00172). The composition of the low- $\mathrm{Ca}^{2+}$ solution was (in mM) $\mathrm{NaCl}, 120 ; \mathrm{KCl}, 2.6 ; \mathrm{NaHCO}_{3}, 1 ; \mathrm{NaH}_{2} \mathrm{PO}_{4}, 0.5$; Na pyruvate, 1 ; HEPES, 4 ; and glucose, $16(\mathrm{pH}$ adjusted to 7.2 with $\mathrm{NaOH}$ ). After the retinas were rinsed with a standard solution three times, they were mechanically triturated using a large-tip pipette (approximately $1.5-\mathrm{mm}$ internal diameter). The standard solution contained (in mM) NaCl, $120 ; \mathrm{KCl}, 2.6 ; \mathrm{CaCl}_{2}, 2.5 ; \mathrm{MgCl}_{2}$, 1; glucose, 10 ; HEPES, 10 ; and $0.1 \mathrm{mg} / \mathrm{ml} \mathrm{BSA} \mathrm{(pH} \mathrm{adjusted} \mathrm{to} 7.4$ with $5 \mathrm{~mm} \mathrm{NaOH}$ ). $A$ few drops of cell suspension were placed in uncoated culture dishes 


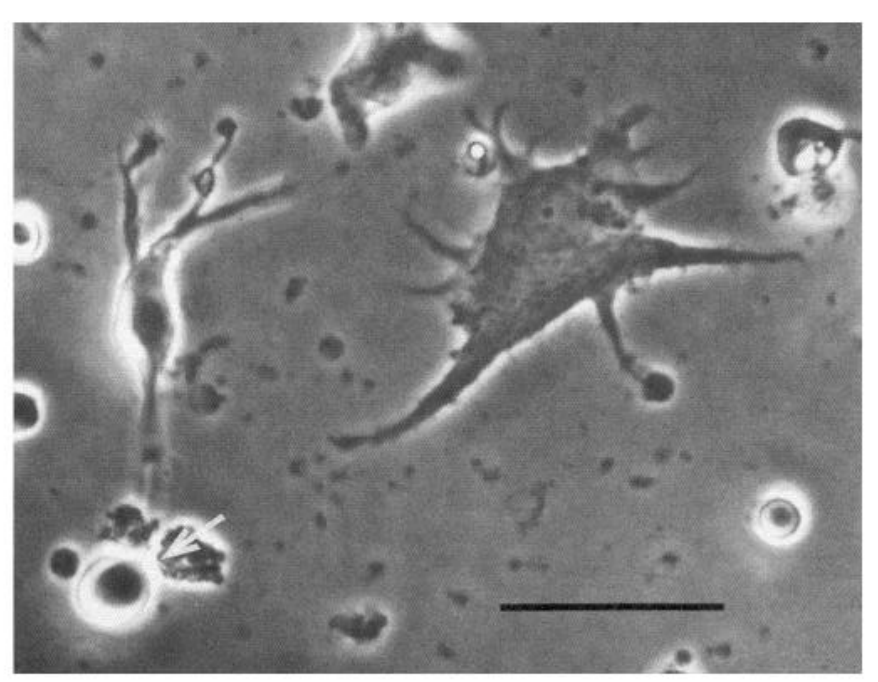

Figure 1. Light micrograph of a goldfish bipolar cell and a catfish horizontal cell. The horizontal cell was cultured for $2 \mathrm{~d}$, and the bipolar cell was freshly dissociated. The horizontal cell was of cone type, and the bipolar cell was of mixed rod/cone ON-type characterized by a large axon terminal (arrow). Scale bar, $30 \mu \mathrm{m}$.

(Falcon 3001) that contained $2 \mathrm{ml}$ Ames's solution (Sigma A-1420; pH adjusted to 7.4 with HEPES buffer) and maintained at $15^{\circ} \mathrm{C}$ for $1-3 \mathrm{~d}$ prior to being used for experiments. In culture, horizontal cells attached to the surface of the dishes and extended fine processes (Fig. 1).

Recordings from horizontal cells. A culture dish containing catfish horizontal cells was inserted into a water jacket mounted on the stage of an inverted microscope equipped with phase-contrast optics (Olympus IMT-2). A stainless-steel ring was put into the dish to reduce the volume of superfusate in the dish and to facilitate heat exchange. Cells were continuously superfused with the standard solution pumped at the rate of $0.24-0.60 \mathrm{ml} / \mathrm{min}$. Experiments were performed at a temperature between $15^{\circ} \mathrm{C}$ and $16^{\circ} \mathrm{C}$.

Cone horizontal cells, which were smaller in size (Naka and Carraway, 1975 ) and more sensitive to L-glutamate than rod horizontal cells (not illustrated), were voltage clamped by a patch pipette (resistance measured in the bath solution, approximately $10 \mathrm{M} \Omega$ ) in the whole-cell recording configuration (Hamill et al., 1981). The patch pipette contained (in mм) $\mathrm{CsCl}, 110 ; \mathrm{CaCl}_{2}, 0.5$; EGTA, $5 ; \mathrm{MgCl}_{2}, 2 ; \mathrm{Na}_{2} \mathrm{ATP}, 5$; HEPES, 10 (pH adjusted to 7.2 with $\mathrm{CsOH}$ ). $\mathrm{Cs}^{+}$in the pipette solution almost completely suppressed outward $\mathrm{K}$ currents activated by membrane depolarization (Shingai and Christensen, 1986), and the remaining outward current was not reduced in amplitude even when tetraethylammonium (TEA; $10 \mathrm{~mm})$ and $\mathrm{Cs}^{+}(10 \mathrm{~mm})$ were applied to the external surface of the cell (not illustrated).

L-Glutamate and its analogs dissolved in superfusate were applied through a Y-tube microflow system (Suzuki et al., 1990). Its outlet was positioned near $(<200 \mu \mathrm{m})$ the cell under investigation. This microflow system enabled us to apply known concentrations of various pharmacological compounds to the same cell during a recording session. L-Glutamate ( $200 \mathrm{~mm} \mathrm{Na}$ salt dissolved in pure water) was sometimes applied from a micropipette positioned close to the cell membrane by ionophoresis (intensity, -10 to $-40 \mathrm{nA}$; duration, $10-100 \mathrm{msec}$; braking current, 0 to $+10 \mathrm{nA}$ ).

Horizontal cells as a probe of excitatory amino acids. Catfish horizontal cells were much more sensitive to L-glutamate than goldfish horizontal cells, as illustrated in Figure 2. The apparent $K_{m}$ value for catfish horizontal cells was approximately $5 \mu \mathrm{M}(4.8 \pm 1.1$, mean \pm SD; $n=4$ ), while that for goldfish horizontal cells was approximately $30 \mu \mathrm{M}$ $(28.0 \pm 2.9 ; n=3)$. The Hill coefficient was close to 1 for the former cells and 2 for the latter cells. Catfish horizontal cells could detect submicromolar concentrations of L-glutamate and thus were suitable for our purpose.

To identify the subtype(s) of glutamate receptors, various glutamate analogs were applied to the horizontal cells. The cells were voltage clamped at a positive potential $(+30$ or $+40 \mathrm{mV})$, because it has been demonstrated that NMDA-activated channels are blocked by external

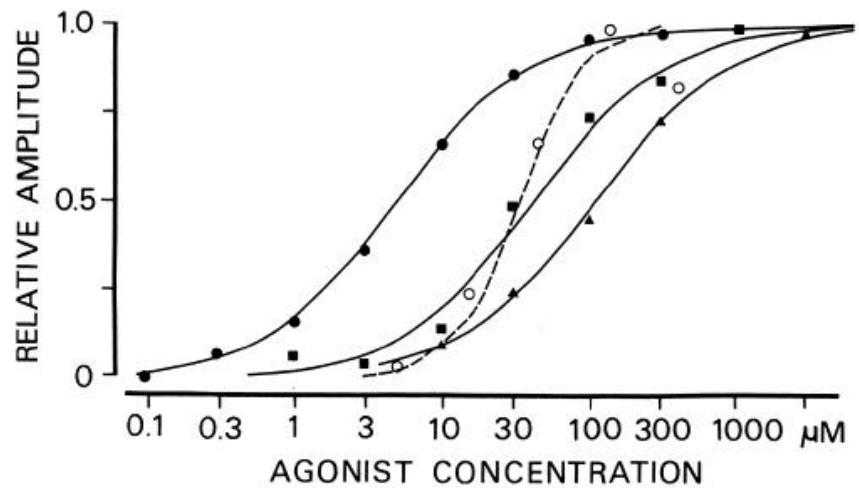

Figure 2. Dose-response curves obtained from catfish horizontal cells (solid symbols) and from goldfish horizontal cells (open circles). Catfish horizontal cells were voltage clamped at $+40 \mathrm{mV}$, and various concentrations of glutamate agonists were applied from the Y-tube microflow system. Averaged data obtained from four catfish horizontal cells were fit to the curve calculated by the Michaelis-Menten equation. The apparent $\mathrm{K}_{\mathrm{m}}$ values were $5 \mu \mathrm{M}$ for L-glutamate (solid circles; $V_{\max }=259$ $\pm 78 \mathrm{pA}$ ), $35 \mu \mathrm{M}$ for NMDA (solid squares; $V_{\max }=140 \pm 47 \mathrm{pA}$ ), and $110 \mu \mathrm{M}$ for L-aspartate (solid triangles; $V_{\max }=244 \pm 56 \mathrm{pA}$ ). L-Glutamate-induced responses of goldfish horizontal cells (holding potential at $-50 \mathrm{mV} ; n=3$ ) could be fit to a curve (broken line) with the Hill coefficient of 2 and the apparent $\mathrm{K}_{\mathrm{m}}$ value of $30 \mu \mathrm{M}\left(V_{\max }=92 \pm 23\right.$ $\mathrm{pA})$.

$\mathrm{Mg}^{2+}$ at negative potentials (Nowak et al., 1984). Catfish horizontal cells responded not only to L-glutamate $\left(\mathrm{K}_{\mathrm{m}}=5 \mu \mathrm{M}\right)$ but also to NMDA $\left(\mathrm{K}_{\mathrm{m}}\right.$ $=35 \mu \mathrm{M})$, L-aspartate $\left(\mathrm{K}_{\mathrm{m}}=110 \mu \mathrm{M}\right.$; Fig. 2), quisqualate $\left(\mathrm{K}_{\mathrm{m}}=1.5 \mu \mathrm{M}\right)$, and kainate $\left(\mathrm{K}_{\mathrm{m}}=30 \mu \mathrm{M}\right.$; not illustrated). In contrast, goldfish horizontal cells were sensitive to L-glutamate, quisqualate, and kainate but insensitive to L-aspartate and NMDA (not illustrated, but see Ishida et al., 1984; Tachibana, 1985)

The voltage dependence of the L-glutamate-induced current $\left(I_{\mathrm{Glu}}\right)$ was nonlinear; the current-voltage $(I-V)$ relation was J-shaped, and the reversal potential was close to $0 \mathrm{mV}$ (see Fig. $5 B$ ). Application of $\mathrm{L}$-aspartate or NMDA resulted in a similar J-shaped $I-V$ relation, but quisqualate- or kainate-induced responses showed a rather linear $I-V$ relation. The nonlinear $I-V$ relation was mainly caused by the voltagedependent blockade of NMDA receptors by extracellular $\mathrm{Mg}^{2+}$, because the negative-conductance region of the $I-V$ curve disappeared and the $I-V$ curve became more linear after removal of $\mathrm{Mg}^{2+}$ from the superfusate (not illustrated). In the release experiments, horizontal cells were usually voltage clamped at positive potentials $(>+30 \mathrm{mV})$ to avoid the blockade of NMDA receptors by $\mathrm{Mg}^{2+}$.

Although glycine itself did not induce any responses, the $I_{\text {Glu }}$ of catfish horizontal cells was potentiated by glycine (Fig. 3, circles), as initially reported by Johnson and Ascher (1987) in CNS neurons. This potentiation was due to activation of NMDA receptors, because NMDAevoked responses were augmented (Fig. 3, squares), but the responses induced by kainate or quisqualate were not affected by glycine (not illustrated). $I_{\mathrm{Glu}}$ increased in amplitude to $151 \pm 24 \%(n=4)$ over the control value $(100 \%)$ at $0.1 \mu \mathrm{M}$, and to $183 \pm 43 \%$ at $10 \mu \mathrm{M}$ (near maximal potentiation). In the release experiments, the solution containing $10 \mu \mathrm{M}$ glycine was ejected from the Y-tube microflow system to potentiate responses evoked by activation of NMDA receptors.

When L-glutamate was continuously applied onto horizontal cells, either from the Y-tube microflow system or from the L-glutamate-filled ionophoretic micropipette, the evoked response did not decay appreciably with time (see Fig. 3, inset). These results indicate that glutamate receptors of the horizontal cells did not significantly desensitize. Therefore, any decline in the horizontal cell response with time would indicate a decrease in the local glutamate concentration, and not a desensitization of their glutamate receptors.

Kynurenic acid was a potent blocker of L-glutamate-evoked responses of catfish horizontal cells. Thirty micromolar kynurenic acid caused $50 \%$ suppression, and a dose of $500 \mu \mathrm{M}$ reduced the $I_{\mathrm{Glu}}$ to $19 \pm 4 \%$ $(n=7)$.

We also examined the effects of various substances, such as $\mathrm{ACh}$, GABA, glycine, 5-HT, dopamine, epinephrine, norepinephrine, and 
ATP (100 $\mu \mathrm{M}$ each) on the horizontal cells. Among these, only GABA evoked a small response (not illustrated). Even when a saturating dose of GABA (1 mM) was applied, the amplitude of GABA-evoked responses was much smaller than that of $\mathbf{L}$-glutamate-induced responses recorded at the same potential. The relation between the GABA-evoked current and the membrane potential was almost linear. The reversal potential was approximately $0 \mathrm{mV}$, which was close to the equilibrium potential for $\mathrm{Cl}^{-}$under our recording conditions. Thus, GABA seemed to activate $\mathrm{GABA}_{\mathrm{A}}$ receptors coupled with a $\mathrm{Cl}$ pore, which have been shown to be antagonized by bicuculline (Lasater et al., 1984). We cannot neglect the possibility that a part of the GABA-induced current may be carried by an electrogenic GABA transporter that has no reversal potential (Malchow et al., 1990).

Although dopamine itself did not induce any current, $100 \mu \mathrm{M}$ dopamine increased the amplitude of the $I_{\text {Glu }}$ by approximately $20 \%$ (not illustrated). Knapp and Dowling (1987) showed that kainate receptors were potentiated by intracelluar cAMP, which was produced by activation of dopamine-stimulated adenylate cyclase. Thus, in our release experiments, horizontal cells were voltage clamped with patch pipettes containing $500 \mu \mathrm{M}$ cAMP to augment the responses evoked by activation of kainate receptors.

We reach the conclusion that catfish horizontal cells contain at least three types of glutamate receptors (NMDA type, kainate type, and quisqualate type) and $\mathrm{GABA}_{\mathrm{A}}$ receptors.

Preparation of bipolar cells. Bipolar cells were obtained from the retina of goldfish (total body length, $15-20 \mathrm{~cm}$ ). The dissociation procedure was the same as mentioned above, except that the goldfish retinas were treated with two kinds of enzyme solution: first with the low- $\mathrm{Ca}^{2+}$ solution containing hyaluronidase $(0.1 \mathrm{mg} / \mathrm{ml}$; Sigma H-3506) to remove the vitreous humor, and then with the low- $\mathrm{Ca}^{2+}$ solution containing cysteine-activated papain.

Goldfish bipolar cells were readily identified by their characteristic morphology. Among them, we selected cells with a large, bulblike axon terminal, as shown in Figure 1. These are ON-type cells that receive input from both rods and cones in the retina (Saito and Kujiraoka, 1982). The cells were used for release experiments within a few hours of dissociation.

Recording procedures for release experiments. A culture dish containing catfish horizontal cells was mounted on the stage of an inverted microscope, and a freshly prepared goldfish retinal cell suspension was added. After the goldfish cells settled down on the surface of the dish, the standard solution was introduced by a peristaltic pump at the rate of $0.24 \mathrm{ml} / \mathrm{min}$, and cells were continuously superfused. Catfish and goldfish horizontal cells were readily distinguished; the former cells were large and attached firmly to the bottom surface of the dish, while the latter cells were small and changed their position slowly with the flow of superfusate.

A bipolar cell with a large axon terminal was voltage clamped using a patch pipette in the whole-cell recording configuration. The pipette was filled with pipette solution without cAMP (resistance in bath was approximately $10 \mathrm{M} \Omega$ ). The pipette was positioned at the axon terminal of the bipolar cell to improve the space-clamp condition at the axon terminal and to make better contact with the apposed horizontal cell. Freshly dissociated bipolar cells did not attach firmly to the dish, and thus the voltage-clamped bipolar cell could be lifted up by manipulating the recording pipette. During transportation, the membrane potential was maintained at a potential negative to $-60 \mathrm{mV}$ to prevent activation of the Ca current $\left(I_{\mathrm{Ca}}\right)$. While the bipolar cell was held approximately $100 \mu \mathrm{m}$ above a catfish horizontal cell, the horizontal cell was voltage clamped at $+40 \mathrm{mV}$ in the whole-cell recording configuration by another patch pipette filled with pipette solution supplemented with $500 \mu \mathrm{M}$ cAMP. The bipolar cell was then slowly lowered onto the horizontal cell until the axon terminal of the bipolar cell was slightly dimpled by the recording pipette, to minimize the extracellular space between them. Pharmacological compounds were ejected to the pair of cells from the Y-tube microflow system or were applied by ionophoresis.

Current and voltage signals from two patch amplifiers (Nihon Kohden, CEZ-2200) were monitored on an oscilloscope and a pen recorder and stored by a PCM recorder (Sony PC-108M; DC to $10 \mathrm{kHz}$ ). At the same time, data were passed through a low-pass filter (NF Electronic Instruments, Yokohama, SR-4FL) to eliminate aliasing, sampled and digitized by an $\mathrm{A} / \mathrm{D}$ converter (Canopus, ADX-98H; sampling speed, between 0.1 and $1 \mathrm{kHz}$ ) connected to a computer (NEC, PC9801-RX), and stored on a hard disk for later analysis.

Each result reported in this article was based on observations obtained from at least three pairs of bipolar and horizontal cells.

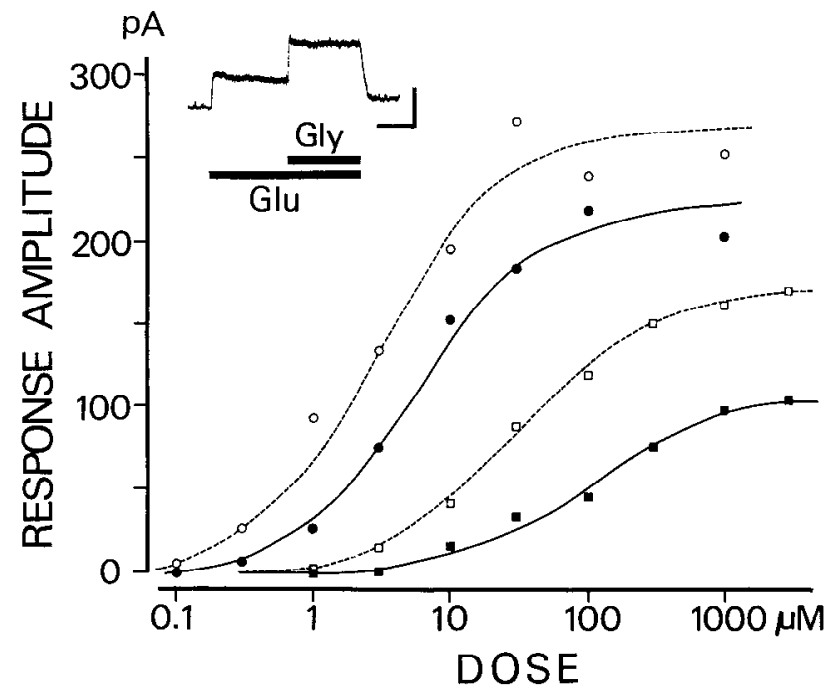

Figure 3. Potentiation of L-glutamate- and NMDA-induced responses by glycine. The inset illustrates the current trace recorded from a catfish horizontal cell voltage clamped at $+40 \mathrm{mV}$. The outward current evoked by $3 \mu \mathrm{M} \mathrm{L}$-glutamate was potentiated by the presence of $10 \mu \mathrm{M}$ glycine. Calibration: $100 \mathrm{pA}, 10 \mathrm{sec}$. The dose-response curves were obtained in the absence (solid symbols) and presence (open symbols) of $10 \mu \mathrm{M}$ glycine. Both L-glutamate-induced responses (circles) and NMDA-induced responses (squares) increased in amplitude by $10 \mu \mathrm{M}$ glycine. The curves were calculated by the Michaelis-Menten equation.

\section{Results}

Release of endogenous substance from bipolar cells Responses of horizontal cells induced by the stimulation of bipolar cells

When an isolated bipolar cell was depolarized from -60 to -20 $\mathrm{mV}$ by a 500 -msec voltage pulse (Fig. $4 A$, top), an inward current ( $>200 \mathrm{pA}$ ) was evoked in the bipolar cell (Fig. $4 A$, middle), and an outward current (approximately $40 \mathrm{pA}$ ) was recorded from an apposed horizontal cell maintained at $+40 \mathrm{mV}$ (Fig. $4 A$, bottom).

The inward current recorded from the bipolar cell was mainly carried by $\mathrm{Ca}^{2+}$, because the outward $\mathrm{K}$ currents had been blocked by $\mathrm{Cs}^{+}$in the pipette solution (see Materials and Methods), and because this inward current was suppressed completely by extracellularly applied $\mathrm{Cd}^{2+}(500 \mu \mathrm{M}$; see Figs. 8, 9). After cessation of the depolarizing pulse, we sometimes observed a slow inward tail current, which lasted a few seconds (Fig. 4A, middle; see also Figs. 7, 9). This tail current may be related to the $\mathrm{Ca}^{2+}$ influx, because it could be blocked by $\mathrm{Cd}^{2+}$ (see Fig. 9). Properties of this slow tail current were not analyzed further.

The outward current recorded from the horizontal cell was elicited only with depolarizing voltage pulses to the bipolar cell. Voltage pulses with opposite polarity in the bipolar cell evoked no response in the horizontal cell (Fig. $4 B$, bottom). A small inward current was induced in the bipolar cell with hyperpolarization (Fig. 4B, middle), the amplitude of which increased slowly during application of the voltage pulse. This current seemed to be an h-current because it was blocked by external $\mathrm{Cs}^{+}$(not illustrated) and because its activation kinetics were similar to those of the h-current reported in the same preparation (Kaneko and Tachibana, 1985).

When the axon terminal of the bipolar cell was lifted up and the distance between the axon terminal and the horizontal cell 
Figure 4. Responses induced by the substance released from a bipolar cell. Membrane potential (top traces) of a bipolar cell $(B C)$ was changed from -60 to $-20 \mathrm{mV}(A)$ or to $-100 \mathrm{mV}(B)$ for $500 \mathrm{msec}$. The apposed horizontal cell $(H C)$ was voltage clamped at $+40 \mathrm{mV}$. The pair of cells was continuously microsuperfused with the solution containing $10 \mu \mathrm{M}$ glycine ejected from the Y-tube microflow system. Currents were low-pass filtered at $100 \mathrm{~Hz}$.

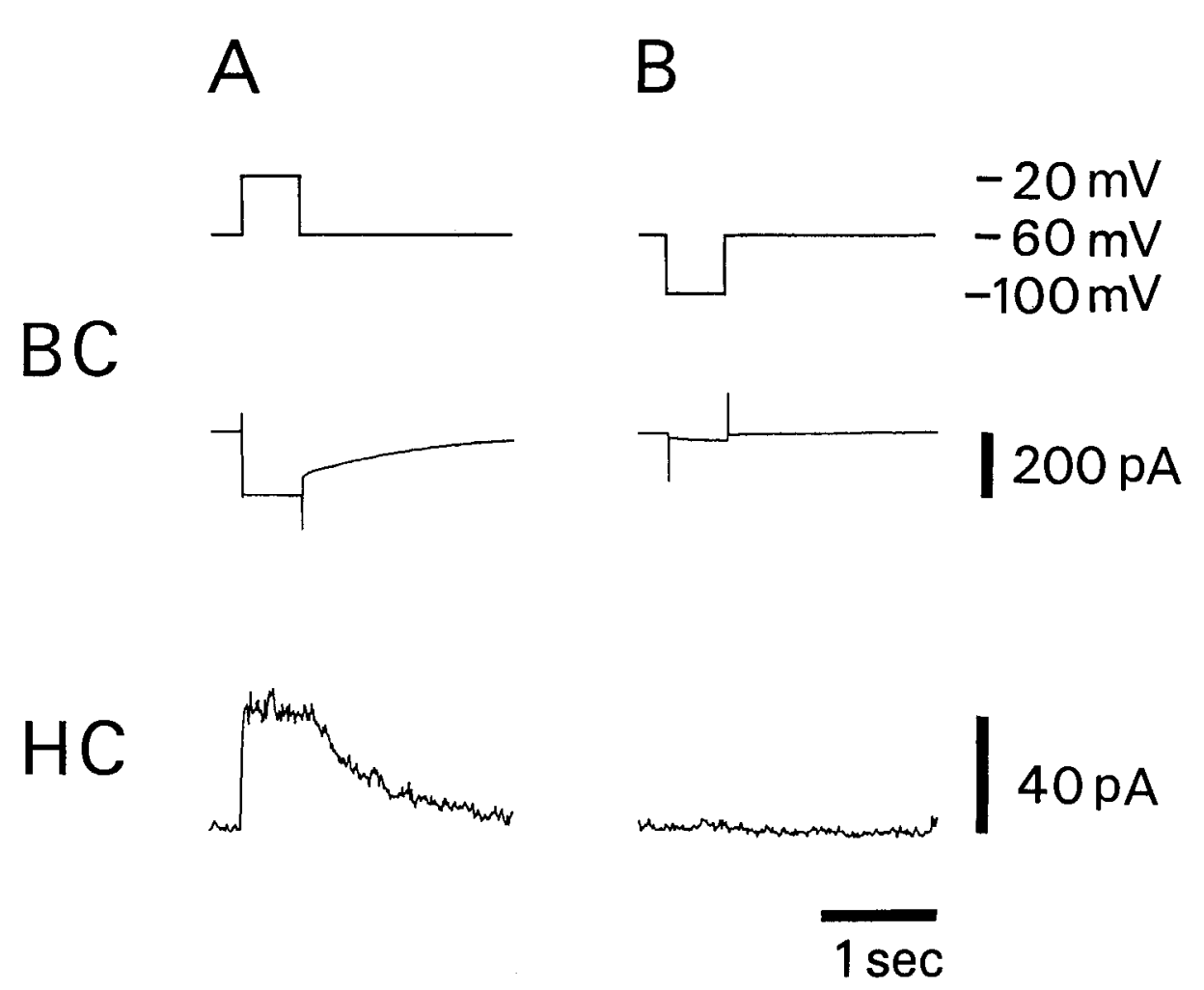

$1 \mathrm{sec}$ increased to more than $100 \mu \mathrm{m}$, depolarization of the bipolar cell induced no response in the horizontal cell (not illustrated). This observation confirms that the outward current recorded from the apposed horizontal cell was evoked by the substance(s) released from the axon terminal of the bipolar cell.

Initial activation of the current induced by the released substance(s) $\left(I_{\mathrm{rs}}\right)$ began with a short delay after onset of the depolarizing pulse. The range of delay was $1-6 \mathrm{msec}(3.4 \pm 1.4 \mathrm{msec}$, mean $\pm \mathrm{SD} ; n=21$ cells examined). This suggests that most of the paired cells were very closely apposed to each other. Quantitative analysis of the time course of $I_{\mathrm{rs}}$ was not performed in the present study due to several unknown factors, such as the distance between the release sites (probably the regions near the synaptic ribbon) and the glutamate receptors of horizontal cells, the area of horizontal cell membrane affected by the released substance, and the speed and volume of the flow of solution ejected from the Y-tube.

Stable recordings were made from 115 pairs of cells. $I_{\mathrm{rs}}$ was successfully recorded from horizontal cells of 85 pairs. The peak amplitude of $I_{\mathrm{rs}}$ was $22.9 \pm 12.7 \mathrm{pA}(n=85$; holding potential at $+40 \mathrm{mV}) . I_{\mathrm{rs}}$ and $I_{\mathrm{Ca}}$ could usually be evoked by repetitive application of depolarizing pulses (pulse interval, approximately $20-30 \mathrm{sec}$ ) for more than $20 \mathrm{~min}$. Deterioration of $I_{\mathrm{rs}}$ always proceeded faster than the rundown of $I_{\mathrm{Ca}}$; at $20 \mathrm{~min}$ after the initiation of the release experiment, $I_{\mathrm{rs}}$ and $I_{\mathrm{Ca}}$ decreased in amplitude to approximately $30 \%$ and $40 \%$, respectively. In a few cases, we could observe $I_{\mathrm{rs}}$ and $I_{\mathrm{Ca}}$ for more than $1 \mathrm{hr}$.

In the remaining 30 pairs, no $I_{\mathrm{rs}}$ was detectable, though depolarizing pulses (from -70 to $-20 \mathrm{mV}$ ) induced $I_{\mathrm{Ca}}(164 \pm$ $60 \mathrm{pA} ; n=30$ ) in the bipolar cells. Failure to record an $I_{\mathrm{rs}}$ appeared to be due to the damage of the releasing processes during the dissociation procedures. When depolarization of a bipolar cell induced no response in the apposed horizontal cell, replacement of the bipolar cell with others obtained from the same retina did not improve the situation, though the horizontal cell responded well to ionophoretically applied L-glutamate.

\section{Reversal potential of $\mathbf{I}_{r s}$}

The reversal potential was examined to infer the ions that carried $I_{\mathrm{rs}}$. A $50-\mathrm{mV}$ depolarizing pulse was applied to an isolated bipolar cell as the membrane potential of the apposed horizontal cell was stepped to new potential levels (Fig. 5A). An outward $I_{\text {rs }}$ could be recorded when the membrane potential of the horizontal cell was maintained at $+30 \mathrm{mV}$. As the holding potential was changed to less positive values, the outward $I_{\mathrm{rs}}$ decreased in amplitude. At $0 \mathrm{mV}$, the $I_{\mathrm{rs}}$ reversed its polarity to inward. Further shift of the potential to negative values increased the amplitude of the inward $I_{\mathrm{rs}}$. During this experiment, the $I_{\mathrm{Ca}}$ induced by $50-\mathrm{mV}$ depolarization did not show any sign of rundown (Fig. 5A). The reversal potential of the $I_{\mathrm{rs}}$ was estimated to be $2.3 \pm 2.4 \mathrm{mV}(n-10)$.

The bipolar cell was then lifted up, and a micropipette filled with L-glutamate was positioned near the same horizontal cell. Before and during the ionophoretic application of L-glutamate, the $I-V$ relation of the horizontal cell was measured using a voltage ramp. The voltage dependence of $I_{\text {Glu }}$ was estimated by the difference between two $I-V$ curves obtained in the presence and absence of L-glutamate (Fig. $5 B$ ). The reversal potential of $I_{\mathrm{Glu}}$ was close to $0 \mathrm{mV}(1.6 \pm 2.6 \mathrm{mV} ; n=10)$. There was no significant statistical difference between the reversal potentials of $I_{\mathrm{rs}}$ and $I_{\mathrm{Glu}}$.

$I_{\mathrm{rs}}$ and $I_{\mathrm{Glu}}$ showed similar voltage dependence (Fig. $5 B$ ). The inward current evoked either by the substance(s) released from bipolar cells or by L-glutamate was suppressed at large negative potentials, resulting in the $\mathrm{J}$-shaped $I-V$ relation. This nonlinear property could be explained by the voltage-dependent blockade of NMDA-activated channels by external $\mathrm{Mg}^{2+}$ (see Materials and Methods; Nowak et al., 1984). If the substance released 
A

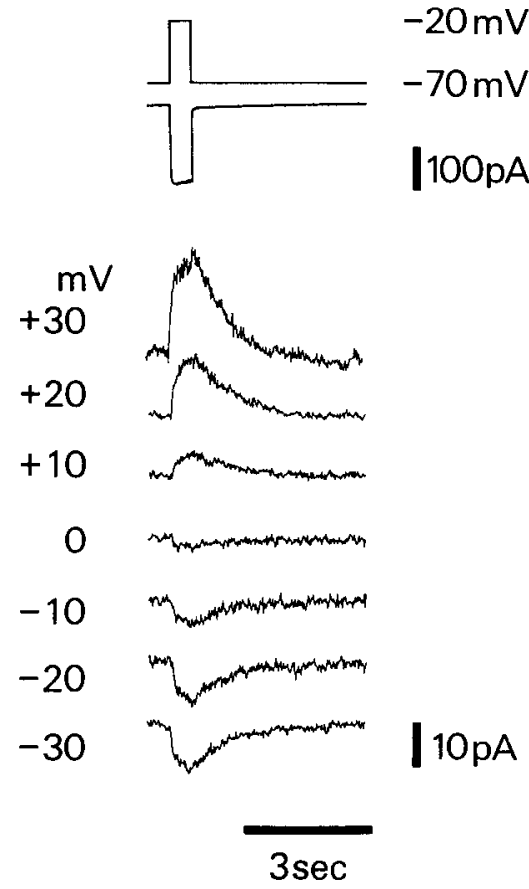

B

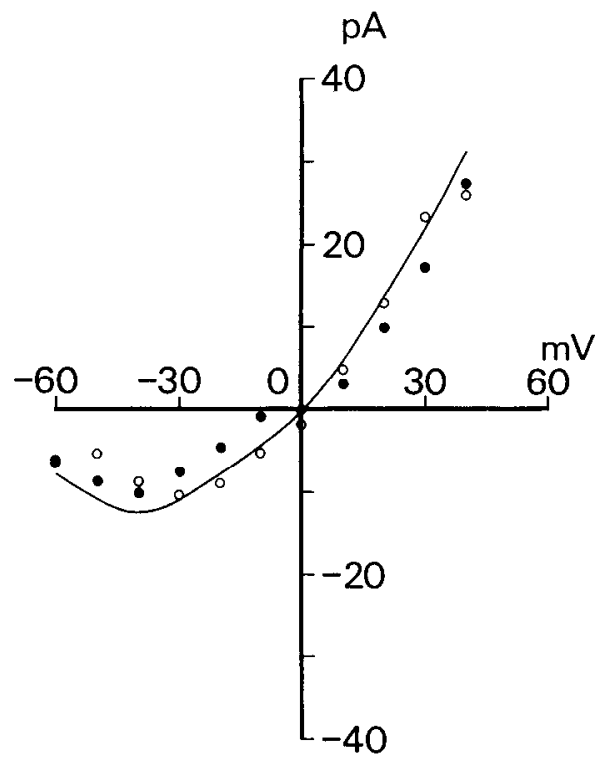

Figure 5. Voltage dependence of $I_{\mathrm{rs}}$ and $I_{\mathrm{Glu}}$. A: Top two records, Voltage command pulse applied to a bipolar cell ( up per record) and superimposed $\mathrm{Ca}$ currents, which were recorded from the bipolar cell when the apposed horizontal cell was voltage clamped at $+30 \mathrm{mV}$, $0 \mathrm{mV}$, and $-30 \mathrm{mV}$ (lower record). Lower seven records, Current traces recorded from the apposed horizontal cell in response to the depolarization of the bipolar cell. Holding potentials are indicated at the left of each trace. Currents were low-pass filtered at $50 \mathrm{~Hz}$. $B$, Peak amplitude of the $I_{\mathrm{rs}}$ was measured from the records shown in $A$ and plotted against the holding potential of the horizontal cell (open circles). Solid circles were similarly obtained after the measurement of $I_{\mathrm{Glu}}-V$ relation (smooth curve). The $I_{\text {Glu }}-V$ relation was obtained by calculating the difference between the $I-V$ curves measured by a voltage ramp $(160 \mathrm{mV} / \mathrm{sec})$ before and during the ionophoretic application of L-glutamate. The intensity ( $2 \mathrm{nA})$ of the ionophoresis was adjusted to produce a current comparable to the $I_{\mathrm{rs}}$ at +30 $\mathrm{mV}$. from bipolar cells were GABA, the $I-V$ relation would be linear (see Materials and Methods). This evidence further indicates that L-glutamate or a closely related compound is released from bipolar cells.

\section{Effect of extracellular $\mathrm{Na}^{+}$on $\mathrm{I}_{r s}$}

To determine the ionic species carrying $I_{\mathrm{rs}}$, we investigated the effect of extracellular $\mathrm{Na}^{+}$on the amplitude of $I_{\mathrm{rs}}$. When 125 $\mathrm{mM} \mathrm{Na}{ }^{+}$was present in the superfusate, both $I_{\mathrm{rs}}$ and $I_{\mathrm{Glu}}$ reversed their polarity between 0 and $+10 \mathrm{mV}$ (see Fig. 5). When external $\mathrm{Na}^{+}$was decreased to $35 \mathrm{mM}$ by replacing $\mathrm{Na}^{+}$with choline, both reversal potentials shiftcd to $\cdots 15 \mathrm{mV}\left(I_{\mathrm{rs}}, \cdots 14.1 \pm 0.4\right.$ $\mathrm{mV} ; I_{\mathrm{Glu}},-15.6 \pm 4.2 \mathrm{mV} ; n=3$; not illustrated). The reversalpotential shifts were approximately half of the value $(-32 \mathrm{mV})$ expected from the Nernst equation, suggesting that both the released substance and L-glutamate opened nonselective cation channels (Hals et al., 1986). It is unlikely that the substance released from bipolar cells activated the GABA-gated $\mathrm{Cl}$ channels of horizontal cells.

\section{Contribution of NMDA receptors to $\mathrm{I}_{r s}$}

An important feature of NMDA receptors is that glycine potentiates the current through NMDA-gated channels (Johnson and Ascher, 1987; see also Fig. 3). As illustrated in Figure 6, 10 $\mu \mathrm{M}$ glycine increased the amplitude of $I_{\mathrm{rs}}$ to approximately $150 \%$ of the control value without affecting $I_{\mathrm{Ca}}$. The potentiation by glycine and the nonlinear $I_{\mathrm{rs}}-V$ relation suggest that NMDA rcceptors of horizontal cells were activated by the substance released from bipolar cells.

\section{Effects of glutamate antagonist}

Application of $500 \mu \mathrm{M}$ kynurenic acid, an antagonist of glutamate receptors, suppressed the amplitude of $I_{\mathrm{rs}}$ to approximately $20 \%$ of the control (Fig. 7). The same concentration of kynurenic acid blocked the $I_{\mathrm{Glu}}$ to a similar degree (see Materials and Methods). The $I_{\mathrm{Ca}}$ was not affected by kynurenic acid. After kynurenic acid was washed out, responses of the horizontal cell recovered almost completely.

This series of release experiments revealed that depolarization of ON-type bipolar cells with mixed $\mathrm{rod} / \mathrm{cone}$ inputs triggered the release of substances that could activate the glutamate receptors of horizontal cells.

To get an insight into the amount of released glutamate-like substance, the response amplitude of the $I_{\mathrm{rs}}$ evoked by $500-\mathrm{msec}$ depolarizing pulses was compared with the $I_{\mathrm{Glu}}$ induced by various concentrations of L-glutamate. One micromolar L-glutamate evoked a slightly larger current than $I_{r s}$ (not illustrated).

$\mathrm{Ca}^{2+}$ influx and release of the glutamate-like substance from bipolar cells

Release of transmitter is usually triggered by an influx of $\mathrm{Ca}^{2+}$ into presynaptic terminals (Katz and Miledi, 1969; Llinás et al., 1981). We examined whether $\mathrm{Ca}^{2+}$ was required for the release of the glutamate-like substance from bipolar cells.

\section{Effects of Ca channel blocker}

Depolarization of a bipolar cell from -70 to $-10 \mathrm{mV}$ induced an inward current in the bipolar cell and an outward current $\left(I_{\mathrm{rs}}\right)$ in the apposed horizontal cell (Fig. 8A). Addition of 500 $\mu \mathrm{M} \mathrm{Cd}{ }^{2+}$ to the bathing solution completely blocked the inward current, and the $I_{\mathrm{rs}}$ disappeared (Fig. $8 B$ ). Both currents recovered after $\mathrm{Cd}^{2+}$ was washed out (Fig. $8 C$ ). Thus, the inward current was identified as the $\mathrm{Ca}$ current.

Horizontal cells responded to L-glutamatc applicd by ionophoresis in the presence of $500 \mu \mathrm{M} \mathrm{Cd}^{2+}$, though response amplitude decreased to $76 \pm 6 \%(n=4)$ of the control value (not illustrated). This suggests that influx of $\mathrm{Ca}^{2+}$ is essential for release of the glutamate-like substance from bipolar cells.

\section{Properties of $\mathrm{I}_{C a}$ of bipolar cells}

The $I_{C a}$ was activated at potentials more positive than approximately $-40 \mathrm{mV}$ and reached a maximum amplitude at ap- 


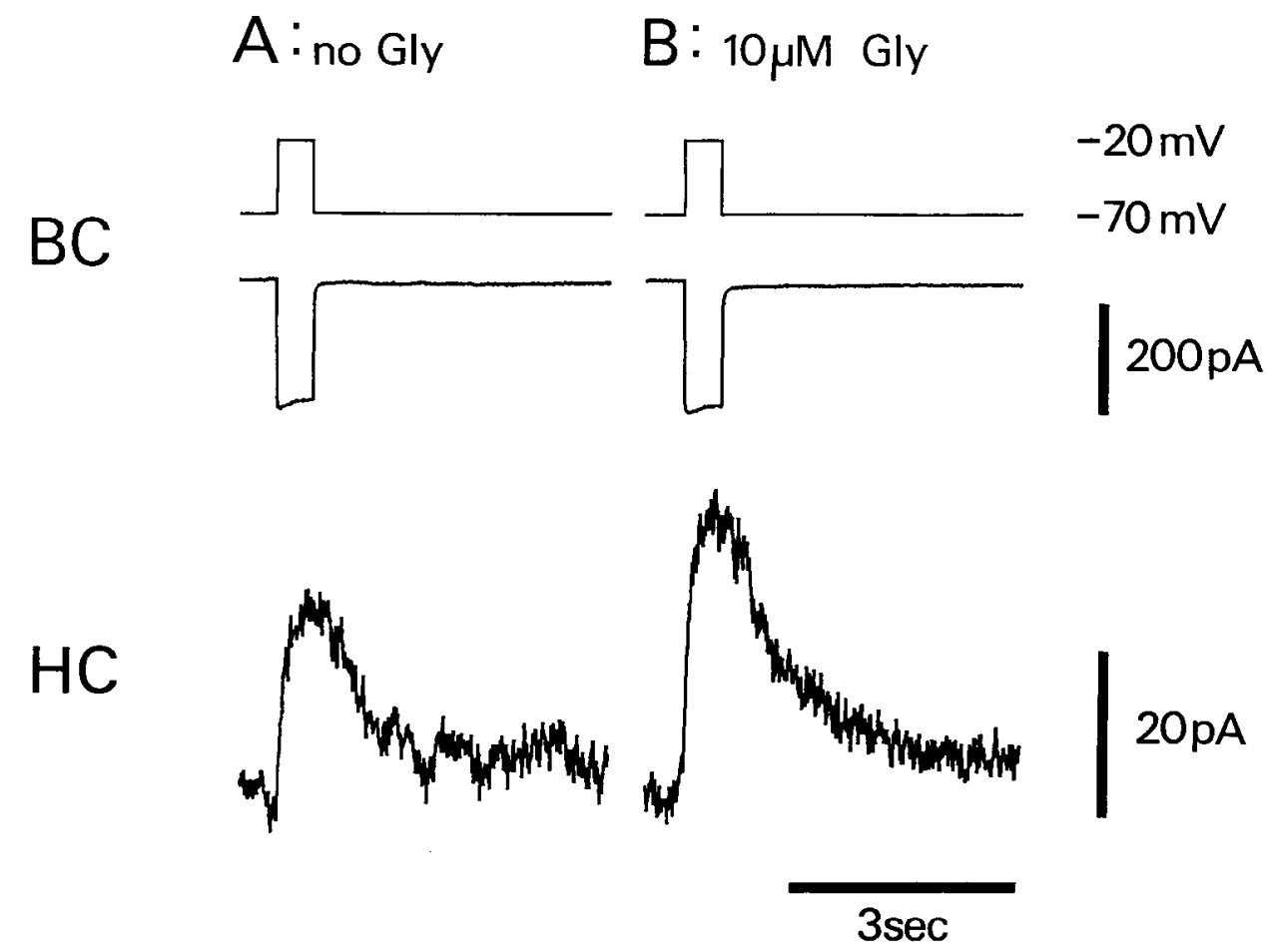

Figure 6. Responses induced by the released substance in the absence $(A)$ and presence $(B)$ of $10 \mu \mathrm{M}$ glycine. When a bipolar cell $(B C)$ was depolarized from -70 to $-20 \mathrm{mV}$ for $500 \mathrm{msec}$, an inward current (middle traces) was induced in the bipolar cell, and an outward current $\left(I_{\mathrm{rs}} ;\right.$ bottom traces) was recorded from the apposed horizontal cell $(H C)$ maintained at $+30 \mathrm{mV}$. Glycine dissolved in the standard solution was ejected from the Y-tube microflow system. Currents were low-pass filtered at $50 \mathrm{~Hz}$.

$$
\text { A: no Gly } \quad B: 10 \mu M \text { Gly }
$$

$-70 \mathrm{mV}$

$200 p A$ proximately $-20 \mathrm{mV}$ (Figs. 9, 10A). Further depolarization reduced the $I_{\mathrm{Ca}}$ amplitude, due to a reduction of the driving force for $\mathrm{Ca}^{2+}$. The permeability sequence was $\mathrm{Ba}^{2+}>\mathrm{Sr}^{2+}>$ $\mathrm{Ca}^{2+}$, and the relative potency of divalent cations in blocking the $I_{\mathrm{Ca}}$ was $\mathrm{Cd}^{2+}>\mathrm{Ni}^{2+}>\mathrm{Co}^{2+}>\mathrm{Mn}^{2+}>\mathrm{Mg}^{2+}(\mathrm{M}$. Tachibana, $\mathrm{T}$. Okada, T. Arimura, and K. Ono, unpublished observations). The $I_{\mathrm{Ca}}$ of goldfish bipolar cells has been shown to be sensitive to dihydropyridines (Kaneko et al., 1989). These observations indicate that the goldfish bipolar cells primarily have sustained, L-type Ca channels (Nowycky et al., 1985).

We could not find a low-threshold, transient $I_{\mathrm{Ca}}$ (T-type; Nowycky et al., 1985) in goldfish bipolar cells. No such current was evoked even when the holding potential was maintained at a potential more negative than $-70 \mathrm{mV}$ or when a hyperpo- larizing conditioning prepulse was applied (not illustrated). Furthermore, such manipulations did not augment the amplitude of $I_{\mathrm{rs}}$ recorded from the apposed horizontal cell.

\section{Relationship between $\mathrm{Ca}^{2+}$ influx and release}

Superimposed traces shown in the middle row of Figure 9 ( $A-$ $D$ ) are the current recordings from a bipolar cell in the absence (traces with asterisks) and presence (traces without asterisks) of $500 \mu \mathrm{M} \mathrm{Cd}^{2+}$. The difference between the two traces indicates the influx of $\mathrm{Ca}^{2+}$ into the bipolar cell.

A small $\mathrm{Ca}^{2+}$ influx induced by depolarization to $-40 \mathrm{mV}$ evoked a small but detectable outward $I_{\mathrm{rs}}$ in the apposed horizontal cell (Fig. 9A, bottom trace with asterisk). A much larger

\section{A CONTROL}

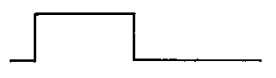

$B C$ acid on Blocking effect of kynurenic leased substance. The endogenous substance was released from a bipolar cell $(B C)$ by depolarization (2-sec pulse from -60 to $0 \mathrm{mV}$; top traces) and detected by an apposed horizontal cell $(H C)$ maintained at $+40 \mathrm{mV}$. Middle traces, $I_{C \mathrm{a}} ;$ bottom traces, $I_{\mathrm{rs}}$. The pair of cells was microsuperfused initially with the standard solution ejected from the $Y$-tube $(A)$, then with the solution containing $500 \mu \mathrm{M}$ kynurenic acid $(B)$, and finally with the standard solution $(C)$. Currents were low-pass filtered at 50 $\mathrm{Hz}$.
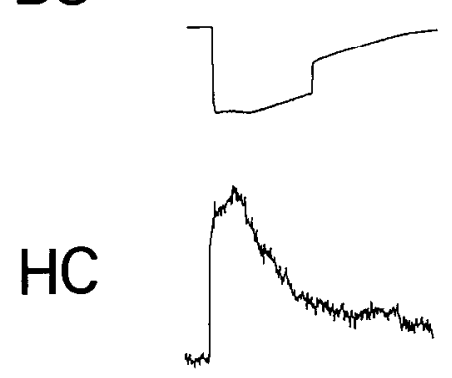

\section{B}

KYNURENIC ACID
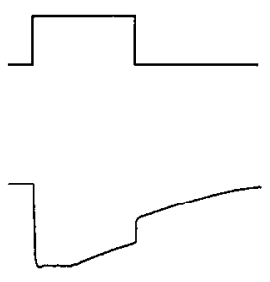

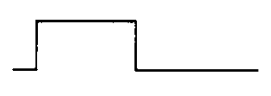

OmV $-60 \mathrm{mV}$

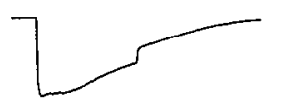

$300 \mathrm{pA}$

C RECOVERY

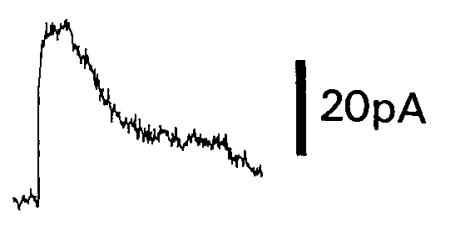

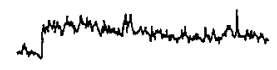

$2 \mathrm{sec}$ 


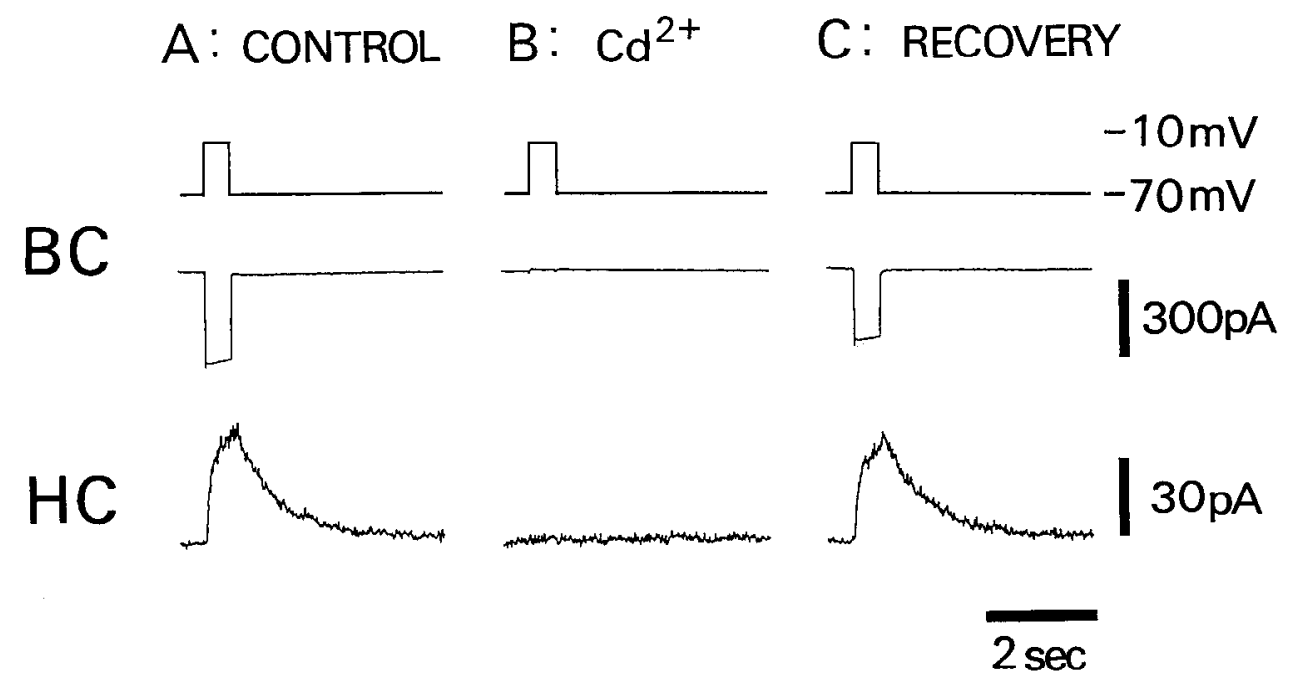

Figure 8. Blocking effects of $\mathrm{Cd}^{2+}$ on $I_{\mathrm{Ca}}$ and $I_{\mathrm{rs}} \cdot A$, Depolarization $(500-\mathrm{msec}$ pulse from -70 to $-10 \mathrm{mV}$; top trace) of a bipolar cell $(B C)$ evoked an inward current (middle trace) in the bipolar cell and an outward current $\left(I_{\mathrm{rs}} ;\right.$ bottom trace) in the apposed horizontal cell (HC) voltage clamped at $+30 \mathrm{mV}$. The pair of cells was continuously microsuperfused with the solution containing $10 \mu \mathrm{M}$ glycine. $B$, The pair was microsuperfused with the solution containing $500 \mu \mathrm{M} \mathrm{Cd}^{2+}$ and $10 \mu \mathrm{M}$ glycine. Both inward and outward currents disappeared. $C$, After $\mathrm{Cd}^{2+}$ was washed out, the responses recovered almost completely. Currents were low-pass filtered at $100 \mathrm{~Hz}$.
$\mathrm{Ca}^{2+}$ influx was evoked by depolarization to $-10 \mathrm{mV}$, resulting in a larger $I_{\mathrm{rs}}$ that exceeded $40 \mathrm{pA}$ in amplitude (Fig. 9B). A depolarization to $+30 \mathrm{mV}$ elicited a smaller $\mathrm{Ca}^{2+}$ influx, and the $I_{\mathrm{rs}}$ decreased in amplitude (Fig. 9C).

Further depolarization to $+60 \mathrm{mV}$ evoked a suble $\mathrm{Ca}^{2}$ influx (Fig. $9 D$, the middle trace with asterisk). During application of the depolarizing pulse, the outward $I_{\mathrm{rs}}$ was very small (Fig. $9 D$, bottom trace with asterisk). However, immediately after the offset of the depolarizing pulse, an off response was clearly recorded from the horizontal cell. When the current trace of the bipolar cell was examined on a faster time scale, an inward tail current was observed immediately after the offset of the depolarizing pulse, which lasted a few milliseconds. This tail current was abolished by application of $\mathrm{Cd}^{2+}$. Therefore, the off response recorded from the horizontal cell was likely triggered by a rapid influx of $\mathrm{Ca}^{2+}$ into the bipolar cell at the cessation of large depolarizing voltage pulses $(>+50 \mathrm{mV})$. Off responses were not observed when bipolar cells were depolarized to potentials less positive than $+40 \mathrm{mV}$, though presence of the prolonged out- ward current triggered by a depolarizing pulse might obscure a small off response evoked at the termination of the pulse (Fig. $9 B, C$ ).

Figure $10 B$ shows the relation between the peak amplitude of $I_{\mathrm{rs}}$ recorded from the horizontal cell versus the command voltage applied to the bipolar cell. This curve and the $I_{\mathrm{Ca}}-V$ curve of the bipolar cell (Fig. 10A) appear as mirror images. The larger the amplitude of $I_{\mathrm{Ca}}$, the larger the amplitude of $I_{\mathrm{rs}}$. However, the relationship between the $I_{\mathrm{Cn}}$ and the $I_{\mathrm{rs}}$ was not quite linear; when the membrane potential of the bipolar cell was changed to $+40 \mathrm{mV}$, the amplitude of the $I_{\mathrm{Ca}}$ decreased to $18 \%$ of the maximum value, while the amplitude of the $I_{\mathrm{rs}}$ was reduced only to $56 \%$ of the maximum value. Similar deviation from a linear relationship was obscrved cven when the charges carried by the $I_{\mathrm{rs}}$ were plotted against the charges carried by the $I_{\mathrm{C} a}$ (not illustrated). Although release of the glutamate-like substance from bipolar cells seemed to be mainly regulated by the influx of $\mathrm{Ca}^{2+}$ through plasma membrane, the relation between $\mathrm{Ca}^{2+}$ influx and release may not be simple.

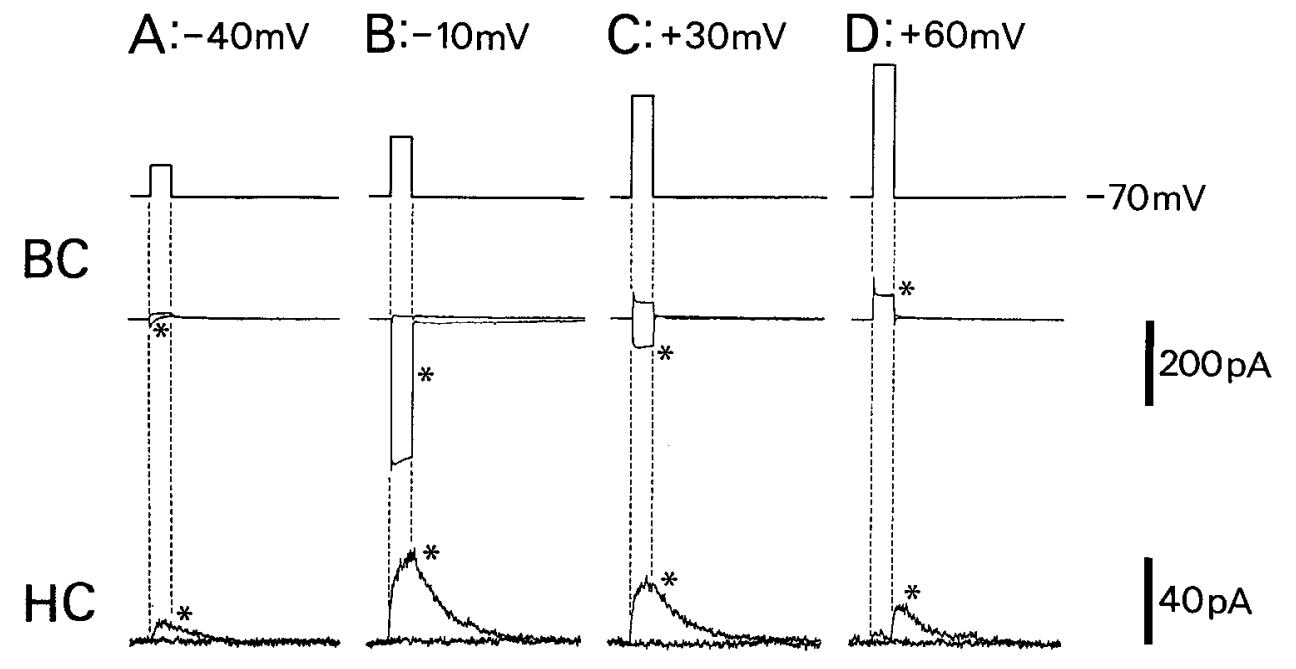

$3 \mathrm{sec}$
Figure 9. Relationship between $I_{\mathrm{Ca}}$ and $I_{\mathrm{rs}}$. Top traces, Membrane potential of a bipolar cell $(B C)$ was changed from $-70 \mathrm{mV}$ to indicated values in the absence and presence of $500 \mu \mathrm{M} \mathrm{Cd}^{2+}$. Middle traces, Two current traces without (asterisks) and with $\mathrm{Cd}^{2+}$ ions were superimposed; thus, the difference indicates the influx of $\mathrm{Ca}^{2+}$ into the bipolar cell. Bottom traces, The currents recorded from the apposed horizontal cell $(H C$; holding potential at $+30 \mathrm{mV}$ ) in the absence (asterisks) and presence of $\mathrm{Cd}^{2+}$. Experiments were performed in the presence of $10 \mu \mathrm{M}$ glycine. Currents were low-pass filtered at $50 \mathrm{~Hz}$. 


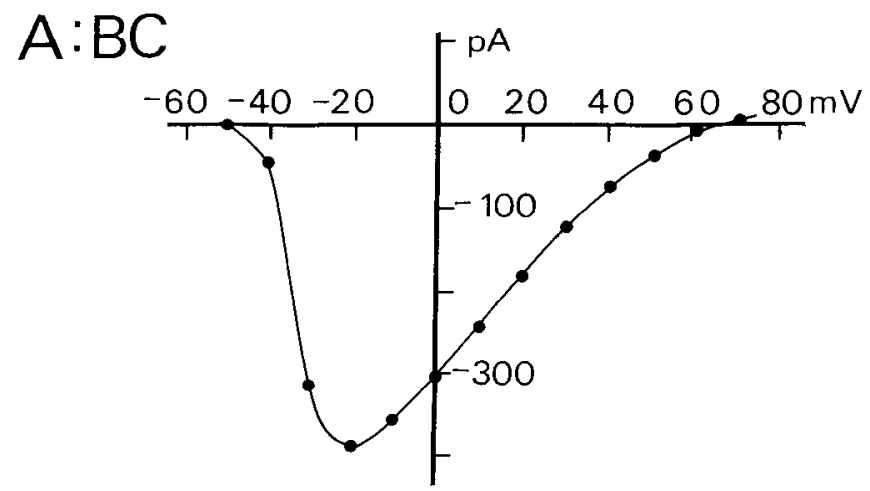

B:HC

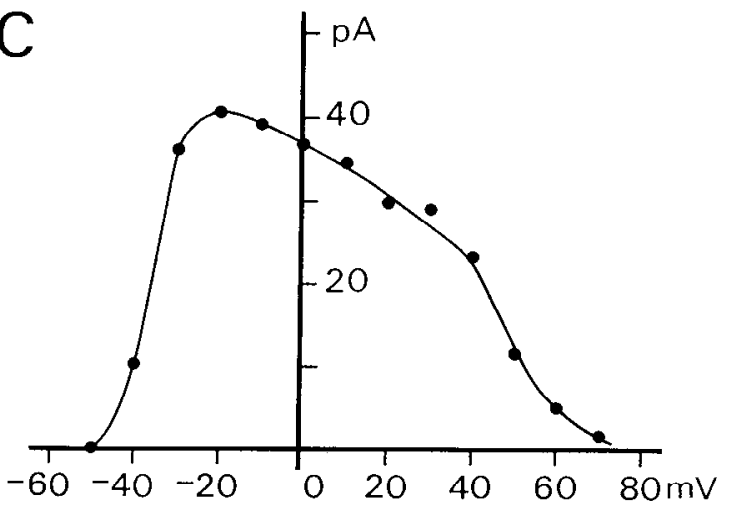

Figure 10. Voltage dependence of $I_{\mathrm{Ca}}$ and $I_{\mathrm{rs}}$. A, A plot of peak amplitude of the $I_{\mathrm{Ca}}$ as a function of the membrane potential of the bipolar cell. $B$, A plot of peak amplitude of the $I_{\mathrm{rs}}$ recorded from the apposed horizontal cell as a function of the membrane potential of the bipolar cell. Data were obtained from the same pair of cells shown in Figure 9.

\section{Discussion}

In the present study, we investigated the release of endogenous substance from mixed rod/cone ON-type bipolar cells isolated from the goldfish retina. When the Ca current was activated by membrane depolarization, bipolar cells released a substance(s) able to interact with glutamate receptors of catfish horizontal cells.

\section{What is the transmitter of mixed rod/cone ON-type bipolar} cells?

Response properties of horizontal cells evoked by the substance released from bipolar cells resembled glutamate-induced responses; reversal potential, nonlinear voltage dependence, permeability to cations, suppression by a glutamate antagonist, and potentiation by glycine. The bulk of the evidence demonstrates that the released substance can interact with glutamate receptors of catfish horizontal cells. Although the chemical identity of the released substance has not been determined, the substance is likely to be L-glutamate or L-aspartate.

Because catfish horizontal cells do not distinguish between L-glutamate and L-aspartate, it is not certain which substance is the transmitter of mixed rod/cone ON-type bipolar cells. However, we are tempted to think that the transmitter may be L-glutamate rather than L-aspartate for the following reasons. First, to produce a response comparable to that evoked by the released substance, it was necessary to apply submicromolar concentrations of L-glutamate, which was less than $1 / 10$ that of L-aspartate. The substances applied from the Y-tube microflow system covered all of the upper surface membrane of the voltage- clamped horizontal cell. On the other hand, the released substance affected a limited area of the surface membrane, that area of which was in contact with the axon terminal of the bipolar cell. Most of the substance that leaked out from this artificial "synaptic cleft" would be washed away by the constant flow of solution coming from the Y-tube microflow system. Taking account of the difference in affected membrane area, $\mathrm{L}$-aspartate would have to be released at the order of $100 \mu \mathrm{M}$. This seems unlikely. Second, it has been demonstrated that the axon terminal of the bipolar cell is highly immunoreactive to L-glutamate (Ehinger et al., 1988; Ehinger, 1989; Marc et al., 1990). This suggests that bipolar cells have a significant amount of endogenous L-glutamate to use as the transmitter.

To distinguish between L-glutamate and L-aspartate, a fluoromctrical method (Ayoub et al., 1989; Schwartz and Tachibana, 1990) would be useful. This technique monitors the production of reduced $\beta$-nicotinamide adenine dinucleotide (NADH) accompanying the catalytic degradation of glutamate by glutamate dehydrogenase, which is specific for L-glutamate and does not recognize L-aspartate.

We cannot reject the possibility that mixed rod/cone ON-type bipolar cells may release excitatory amino acids together with other substances, such as peptides that catfish horizontal cells do not sense. To identify the transmitter of mixed rod/cone ONtype bipolar cells, the physical and chemical nature of the released compound(s) must be examined by other techniques, such as gas chromatography-mass spectrometry (Kawagoe et al., 1984).

\section{Ca channels at the axon terminal of bipolar cells}

Because the distance between the axon terminal and the glutamate probe (horizontal cell) was a critical factor for the detection of release, and because afferent synapses of bipolar cells have been localized to the axon terminal (Witkovsky and Dowling, 1969; Kaneko et al., 1980), it is likely that the glutamatelike substance was released from the axon terminal of the ONtype bipolar cells. The present studies demonstrate that the influx of $\mathrm{Ca}^{21}$ triggered the release. The time lag between the onset of a depolarizing pulse and the initiation of $I_{\mathrm{rs}}$ was less than $6 \mathrm{msec}$. If $\mathrm{Ca}$ channels were located exclusively at the cell body, this short latency could not be explained by the diffusion of $\mathrm{Ca}^{2+}$ from the cell body to the axon terminal. Because the apparent diffusion coefficient for $\mathrm{Ca}^{2+}$ in the cytoplasm is estimated to be approximately $10^{-7} \mathrm{~cm}^{2} \mathrm{sec}^{-1}$ (Augustine et al., 1987), it will take as long as $45 \mathrm{sec}$ for $\mathrm{Ca}^{2+}$ to diffuse from cell body to axon terminal through the axon (approximately $30 \mu \mathrm{m}$ in length). Therefore, Ca channels must cxist at the axon terminal of bipolar cells (see Kaneko et al., 1989).

\section{Signal transmission from bipolar cells to postsynaptic cells}

In our preparation, the $I_{\mathrm{Ca}}$ was clearly activated by depolarization to potentials more positive than $-40 \mathrm{mV}$. On the other hand, photoresponses of bipolar cells in situ cover the potential range between approximately -60 and $-20 \mathrm{mV}$ (Ashmore and Falk, 1980). The transmission of bipolar cell signals to postsynaptic cells more negative than $-40 \mathrm{mV}$ is intriguing.

Because $I_{\mathrm{Ca}}$ is a continuous function of membrane potential, depolarization-release coupling may not have a threshold (see Llinás et al., 1981). A small depolarization $(<-40 \mathrm{mV})$ would induce a small amount of $\mathrm{Ca}^{2+}$ influx, which could release a small amount of transmitter. This amount of transmitter might 
be detected by the postsynaptic cells in situ. However, in our experiments, it may be that such small $I_{\mathrm{Ca}}$ was not detected in the whole-cell clamp configuration and that the horizontal cell could not detect a small amount of released substance.

An alternative (not mutually exclusive) possibility is that photoresponses below $-40 \mathrm{mV}$ may be transmitted to the postsynaptic cells by changing the balance between the release and uptake of transmitter at the synaptic cleft. The transmitter may be continuously released from bipolar cells in the dark, because their membrane potential is maintained at a value slightly positive to $-40 \mathrm{mV}$ (Saito et al., 1979). Bipolar cells might be equipped with an uptake carrier, which may be activated by membrane hyperpolarization, similar to the glutamate carrier of Müller cells (Brew and Attwell, 1987; Schwartz and Tachibana, 1990). The transmitter concentration at the synaptic cleft may be kept at a certain steady level by both mechanisms. Hyperpolarization of bipolar cells below the activation level of $I_{\mathrm{Ca}}$ would stop the transmitter release and facilitate the uptake by carrier, and thus a net reduction of transmitter concentration at the synaptic cleft would hyperpolarize postsynaptic cells.

We cannot reject the possibility that photoresponses of bipolar cells below $-40 \mathrm{mV}$ might be clipped and not be transmitted to the postsynaptic cells. Such signal clipping has been reported at synapses from rods to horizontal cells (Attwell et al., 1987).

Although transmitter release from bipolar cells was augmented by the increase in $\mathrm{Ca}^{2+}$ influx, their relationship was not quite linear. The relation did not fit an exponential function, which has been postulated for the squid giant synapse (Smith et al., 1985). To elucidate the $\mathrm{Ca}^{2+}$-release coupling at synaptic terminals, it is necessary to take into account various factors: voltage dependence for the $\mathrm{Ca}^{2+}$-release coupling (Llinás et al., 1981), cooperativity of presynaptic $\mathrm{Ca}^{2+}$ action (Augustine et al., 1985; Smith et al., 1985), compartmentation of $\mathrm{Ca}^{2+}$ diffusion at presynaptic terminals (Lucker and Fogelson, 1986), $\mathrm{Ca}^{2+}$-induced $\mathrm{Ca}^{2+}$ release from internal Ca stores (Endo, 1985), intermediate processes that regulate transmitter release (Llinás et al., 1985), and so on. The preparation presented in this article can be used as a model system of synaptic transmission and may contribute to the understanding of $\mathrm{Ca}^{2+}$-release coupling at presynaptic terminals.

\section{References}

Aizenman E, Frosch MP, Lipton SA (1988) Responses mediated by amino acid receptors in solitary retinal ganglion cells from rat. $\mathrm{J}$ Physiol (Lond) 396:75-91.

Ashmore JF, Falk G (1980) Responses of rod bipolar cells in the darkadapted retina of the dogfish, Scyliorhinus canicula. J Physiol (Lond) 300:115-150.

Attwell D, Borges S, Wu SM, Wilson M (1987) Signal clipping by the rod output synapse. Nature 328:522-524.

Augustine GJ, Charlton MP, Smith SJ (1985) Calcium entry and transmitter release at voltage-clamped nerve terminals of squid. J Physiol (Lond) 369:163-181.

Augustine GJ, Charlton MP, Smith SJ (1987) Calcium action in synaptic transmitter release. Annu Rev Neurosci 10:633-693.

Ayoub GS, Korenbrot JI, Copenhagen DR (1989) Release of endogenous glutamate from isolated cone photoreceptors of the lizard. Neurosci Res 10:S47-S56.

Barnes S, Werblin F (1987) Direct excitatory and lateral inhibitory synaptic inputs to amacrine cells in the tiger salamander retina. Brain Res 406:233-237.

Bloomfield SA, Dowling JE (1985) Roles of aspartate and glutamate in synaptic transmission in rabbit retina. II. Inner plexiform layer. $\mathrm{J}$ Neurophysiol 53:714-725.

Brew H, Attwell D (1987) Electrogenic glutamate uptake is a major current carrier in the membrane of axolotl retinal glial cells. Nature 327:707-709.

Copenhagen DR, Jahr CE (1989) Release of endogenous excitatory amino acids from turtle photoreceptors. Nature 341:536-539.

Endo M (1985) Calcium release from sarcoplasmic reticulum. Curr Topics Membr Transp 25:181-230.

Ehinger B (1989) Glutamate as a retinal neurotransmitter. In: Neurobiology of the inner retina, Ser $\mathrm{H}$, Cell biology, Vol 31 (Weiler $\mathrm{R}$, Osborne NN, eds), pp 1-14. Berlin: Springer.

Ehinger B, Ottersen OP, Storm-Mathisen J, Dowling JE (1988) Bipolar cells in the turtle retina are strongly immunoreactive for glutamate. Proc Natl Acad Sci USA 85:8321-8325.

Famiglietti EV Jr, Kaneko A, Tachibana M (1977) Neuronal architecture of on and off pathways to ganglion cells in carp retina. Science 198:1267-1269.

Hals G, Christensen BN, O'Dell T, Christensen M, Shingai R (1986) Voltage-clamp analysis of currents produced by glutamate and some glutamate analogues on horizontal cells isolated from the catfish retina. J Neurophysiol 56:19-31.

Hamill OP, Marty A, Neher E, Sakmann B, Sigworth FJ (1981) Improved patch-clamp techniques for high-resolution current recording from cell and cell-free membrane patches. Pfluegers Arch 391:85100.

Hume RI, Roll LW, Fischbach GD (1983) Acetylcholine release from growth cones detected with patches of acetylcholine receptor-rich membranes. Nature 305:632-634.

Ishida AT, Kaneko A, Tachibana M (1984) Responses of solitary retinal horizontal cells from Carassius auratus to L-glutamate and related amino acids. J Physiol (Lond) 348:255-270.

Johnson JW, Ascher P (1987) Glycine potentiates the NMDA response in cultured mouse brain neurons. Nature 325:529-531.

Kaneko A, Tachibana M (1985) A voltage-clamp analysis of membrane currents in solitary bipolar cells dissociated from Carassius auratus. J Physiol (Lond) 358:131-152.

Kaneko A, Tachibana M (1988) L-Glutamate-induced depolarization in solitary photoreceptors: a process that may contribute to the interaction between photoreceptors in situ. Proc Natl Acad Sci USA 85:5315-5319.

Kaneko A, Nishimura Y, Tauchi M, Shimai K (1980) Distribution of afferent synapses along on-center bipolar cell axons in the carp retina. Biomed Res 1:345-348.

Kaneko A, Pinto LH, Tachibana M (1989) Transient calcium current of retinal bipolar cells of the mouse. J Physiol (Lond) 410:613-629.

Kato S, Teranishi T, Negishi K (1985) L-Glutamate depolarizes onoff transient type of amacrine cells in the carp retina: an ionophoretic study. Brain Res 329:390-394.

Katz B, Miledi R (1969) Tetrodotoxin-resistant electric activity in presynaptic terminals. J Physiol (Lond) 203:459-487.

Kawagoe R, Onodera K, Takeuchi A (1984) The uptake and release of glutamate at the crayfish neuromuscular junction. J Physiol (Lond) 354:69-78.

Knapp AG, Dowling JE (1987) Dopamine enhances excitatory amino acid-gated conductances in cultured retinal horizontal cells. Nature 325:437-439.

Lasater EM, Dowling JE (1982) Carp horizontal cells in culture respond selectively to L-glutamate and its agonists. Proc Natl Acad Sci USA 79:936-940.

Lasater EM, Dowling JE, Ripps H (1984) Pharmacological properties of isolated horizontal and bipolar cells from the skate retina. J Neurosci 4:1966-1975.

Llinás R, Steinberg IZ, Walton K (1981) Relationship between presynaptic calcium current and postsynaptic potential in squid giant synapse. Biophys J 33:323-352.

Llinás R, McGuinness TL, Leonard CS, Sugimori M, Greengard P (1985) Intraterminal injection of synapsin I or calcium/calmodulindependent protein kinase II alters neurotransmitter release at the squid giant synapse. Proc Natl Acad Sci USA 82:3035-3039.

Lukasiewicz PD, McReynolds JS (1985) Synaptic transmission at $N$-methyl-D-aspartate receptors in the proximal retina of the mudpuppy. J Physiol (Lond) 367:99-115.

Malchow RP, Oian H, Ripps H (1990) Evidence for electrogenic transport of GABA into cone-driven horizontal cells of the catish retina. Soc Neurosci Abstr 16:465.

Marc RE, Lam DMK (1981) Uptake of aspartic and glutamic acid by photoreceptors in goldfish retina. Proc Natl Acad Sci USA 78:71857189 . 
Marc RE, Liu WS, Kalloniatis M, Raiguel SF, Van Haesendonck E (1990) Patterns of glutamate immunoreactivity in the goldfish retina. J Neurosci 10:4006-4034.

Meriney SD, Young SH, Grinnell AD (1989) Constraints on the interpretation of nonquantal acetylcholine release from frog neuromuscular junctions. Proc Natl Acad Sci USA 86:2098-2102.

Murakami M, Ohtsu K, Ohtsuka T (1972) Effects of chemicals on receptors and horizontal cells in the retina. J Physiol (Lond) 227:899913.

Naka K (1977) Functional organization of catfish retina. J Neurophysiol 40:26-43.

Naka K, Carraway NRG (1975) Morphological and functional identifications of catfish retinal neurons. I. Classical morphology. J Neurophysiol 38:53-71.

Nowak L, Bregestovski P, Asclier P, Herbel A, Proclianilz A (1984) Magnesium gates glutamate-activated channels in mouse central neurones. Nature 307:462-465.

Nowycky MC, Fox AP, Tsien RW (1985) Three types of neuronal calcium channel with different calcium agonist sensitivity. Nature 316:440-443.

O'Dell TJ, Christensen BN (1986) $N$-methyl-aspartate receptors coexist with kainate and quisqualate receptors on single isolated catfish horizontal cells. Brain Res 381:359-362.

O'Dell TJ, Christensen BN (1989) Horizontal cells isolated from catfish retina contain two types of excitatory amino acid receptors. J Neurophysiol 61:1097-1109.

Saito T, Kujiraoka T (1982) Physiological and morphological identification of two types of on-center bipolar cells in the carp retina. J Comp Neurol 205:161-170.

Saito T, Kondo H, Toyoda J (1979) Ionic mechanisms of two types of on-center bipolar cells in the carp retina. J Gen Physiol 73:73-90:

Schwartz EA (1987) Depolarization without calcium can release $\gamma$-aminobutyric acid from a retinal neuron. Science 238:350-355.
Schwartz EA, Tachibana M (1990) Electrophysiology of glutamate and sodium cotransport in a glial cell of the salamander retina. J Physiol (Lond) 426:43-80.

Shingai R, Christensen BN (1986) Excitable properties and voltagesensitive ion conductances of horizontal cells isolated from catfish (Ictalurus punctatus) retina. J Neurophysiol 56:32-49.

Slaughter MM, Miller RF (1983) Bipolar cells in the mudpuppy retina use an excitatory amino acid neurotransmitter. Nature 303:537-538.

Smith SJ, Augustine GJ, Charlton MP (1985) Transmission at voltageclamped giant synapse of the squid: evidence for cooperativity of presynaptic calcium action. Proc Natl Acad Sci USA 82:622-625.

Suzuki S, Tachibana M, Kaneko A (1990) Effects of glycine and GABA on isolated bipolar cells of the mouse retina. J Physiol (Lond) 421: 645-662.

Tachibana M (1981) Membrane properties of solitary horizontal cells isolated from goldfish retina. J Physiol (Lond) 321:141-161.

Tachibana M (1985) Permeability changes induced by L-glutamate in solitary retinal horizontal cells isolated from Carassius auratus. J Physiol (Lond) 358:153-167.

Toyoda J, Fujimoto M (1984) Application of transretinal current stimulation for the study of bipolar-amacrine transmission. J Gen Physiol 84:915-925.

Toyoda J, Hashimoto H, Ohtsu K (1973) Bipolar-amacrine transmission in the carp retina. Vision Res 13:295-307.

Witkovsky P, Dowling JE (1969) Synaptic relationships in the plexiform layers of carp retina. Z Zellforsch 100:60-82.

Young SH, Poo M (1983) Spontaneous release of transmitter from growth cones of embryonic neurones. Nature 305:634-637.

Zucker RS, Fogelson AL (1986) Relationship between transmitter release and presynaptic calcium influx when calcium enters through discrete channels. Proc Natl Acad Sci USA 83:3032-3036. 